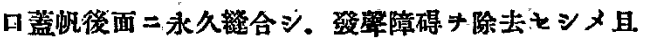

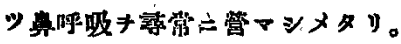

\section{6. 最近二年間二於々ル顠下辞下腺}

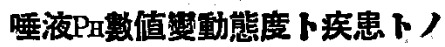

關係山崎 春三(匐㗨)

余八茲二數年間顎下舌下唾液P數值，每:日， 變動ト疾患卜ノ密接關係フ認メテ既ニ發表シ。 更二之カ唯察櫝行中昨年昭和 13 年 4 月. 10 日頃 ヨリ俄二該 $\mathrm{P}$ 數值ノ上昇省覔加セシニ氣ジキ

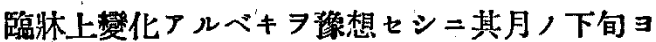
リ入院者，念增加 7 認メ。本科族患 =就テモ注

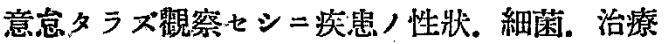
等二於テ例年ト異ナル處多カリシテ以テ之等二 就テ述ベント欲ス。

佾ホ之レア述ブルニ先立チ當校所在地高槻町地 方ノ氣候關係 シー言センニ，當地八京都。大阪 兩市 中間 =アリ氣候關係八東八大山崎（天王 山）西ハ神崎川(或人ノ言) 7 璄トシテ之等 3 地 八大略 3 種＝區別セラル、特性アリ。

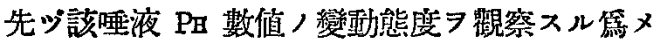
$=$ 每日 $/ \mathrm{PH} 6.9$ 以上者数 7 其月 $\mathrm{PH} 6.9$ 以上者 ，總數 和 13.2 兩年ノ夫レア比較セり。

此兩年度 $\mathrm{PB}$ 數值 $ᄏ$ 检 スル $=12$ 年底=於テハ $\mathrm{PH}$ 6.9 人者多數ナルモ 13 年度 $=$ 於テハ $\mathrm{PH} 7.0$ 以上 者甚ダ多數. 甚ダシキモノ六實 $=$ PE $3.0=$ 及ビ シモノフリ。從ツテ爾曲線間 =大ナル差異 7 來 タセリ(表)。

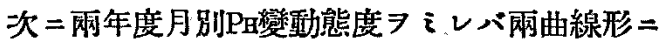
類似性認メラレ一般ニ八暖キ時期二上昇シ．㦛 冷時期二下降（酸性）スル傾问フリ。之レガ 13 年度二於テハ極メテ明膫二認メラレタリ。其他 ，事八表示ス。少木 12 年/冬期八一般=暧. 13
年ノ夫レハ寒氣强キ方ナリキ。 以下臨壯上氮附半シ事叐 7 述ベン。 13年 1 月 2 日出血性中耳炎二于治療上困難厂.》.

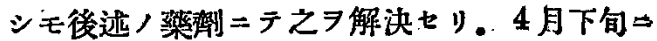

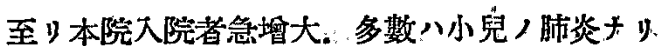
キ。本科二於テ八難聽主訴者多數。此主訴八其 年 1 年 7 通ジテ多數認メラレ 。中耳炎所謂歐氏 管障害等=因七り。份木余八口蓝扇桃㟫䝢栓 そレガ有カナル原因アナセシモノ相當ニ認メ. 其一部ハ近り發表セント欲ス。

6 月二八輕重八兔二角芷性同側三叉神經(主％)

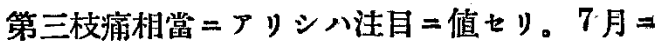
八中耳炎ニシテ食欲缺乏ト下蜊ヨ伴フモ/注意 セラル。

耳揤ハ2 月下旬頃 $コ$ リ 7 月下旬二八長時日（1 週以上）二及ブ激烈ナル疼痛ト耳翼附着部，炎 症性腯脤 耳炎 7 合侀七リ。

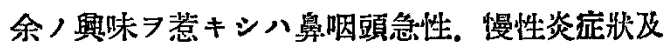
ビ余ガ云フ慢性咽扁炎? 症候群（神經症狀）， 7 訴フル者ハ前年ヨリ甚ダシク減少。殊=4月手 リ12月迄顯著。而シテ該唾液P數值上昇セシ月 二減少シ。下降七シ時＝增加（6月..9月）飞 シ事ナリ。

斯クノ如クシテ 12 月二大ルヤP數值八急激二 下降シ同時：疾患性狀。細菌種等分例年卜同樣 トナル。此嶴咽頭炎症候者八 13 年度二八前年 ト比スレバ多數ナリシハ，冬期氣候氣温關係ノ 意味ヨ知ル二役立ツベシト信ス。 次 =昨年度=於ケル本科疾患，細菌二就テ述べ ン.

昨年 (13年) =於ケル本科疾患. 中耳炎。「アン ギナ」.耳節等ノ細菌 7 檢鏡シ 1 年 7 通ジ殊 $=4$ 
月以降双珠菌例甚ダ多數ニシテ㱠ンド總テトモ 云ハルベシ。而シテ12月二至ルヤ連鑍．葡䔄狀 菌が病筑㿥二多數トナリ例年ト同様トナリタリ。 最後二夫レ等笑患，治療䊾效果，變動 7 迅べ ン。余八昨年 11 月頃迄二效果的二作用セシ八 「グリセリン」ナリト言ハント欲ス。郎チ中耳 炎。「アンギナ」. 耳廐。一般=使用七ラル、藥 用ト合シテ著效ヨ認メタリ。

昨年1月「リペノール」. 醌酸「礬士」等ノ效果 不明. 之ニ「グリセりン」ヨ加へテ有效.「キ= 一ネアスピリン效果擧ラズ.「アスビリンフェ ナセチン」三效果アリ．1年ヨ通ジテ之ヨ使用 ス。「フルンケル」=對スル「オダール」「「テ ンクォレフ」油.「ビオホルムオレーフ」油.「ヨ ード扣里ラ゙リン」等ノ效果ハ湛ダ不充分ナル モ 之ニ「ダリセリン」フ加へテ效果加ハル。

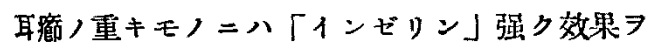

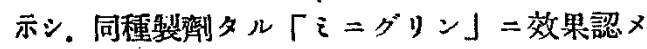

$$
\text { 座 長 } \quad(17-21)
$$

\section{7. 上氣道瀬ニ就テ}

\section{（第一報 臨㸛的萑察）}

義 汇 㼁 雄(憵先宊) 我國內地二於ケル皟患者数ハ米ダ明膫デハナ 1ガ．2-3藏位ダト稱セラレデル。而シテ

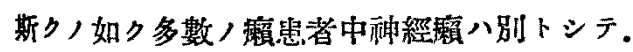

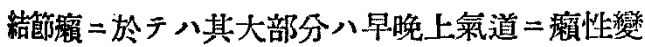
化习起シ，然モ其變化タルヤ死ンド生涯习通ジ テ停止スル所ア知ラヌノデアッテ，上氣道疾患 中顆ハ最モ惨酷ナルモノデアルト言ツテモ過言 デハナ1。郎チ之等變化》殆ント上氣道ノ至ル

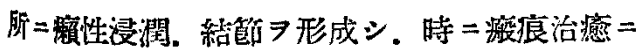

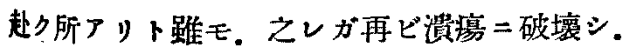
类縮。族痕收縮习承タシ。斯クシテ永イ經過，
カネタルハ興味アリ。

纷木昨年 5.6月二一時中耳炎二對スル「アル コール」效果不明トナリシ事モ注意二值スへ シ.

そヨ要スルニ 1 ケ年二於ケル耳鼻咽喉科疾息

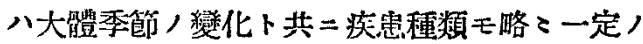
軌道 意习㬇起七ザルヨ常トスルモ。昨年度ニ於ケル 氣候ノ變調卜咨患，變調トハ余トシテハ看過七 ラレザルモノアリ．殊=之ガ 4 月二於ケル预舌 下䟚液P數储, 異常上昇二注意フ促サレタル關 係モフルナランモ。余八該唾液 $\mathrm{P}$ 數值. 氣象氣 候。疾㭧卜，間二八極メテ密接さル關係ノアル 事. 同時二藥物效果ナルモノ八藥物學が示ス如

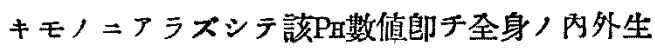
活漓況 =ョリテ變動スルコト．更二资患ノ原因 トシテ今日ノ如ク醫學ガ細菌フ重要视スル事ハ 再考习要スル事ナルベシ。

\section{香宗我部 落}

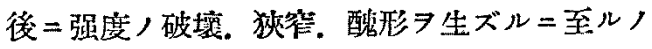
デアル。

上氣道㨨 $=$ 關スル論文八外國 $=$ 於テハ䠶 $=19$ 世紀末ョリ發表七ラレテキルガ。其症例數八就 レモ極メテ少ク，且ツ其檢查方法二モ缺クル所 ガ少クナ1。我國二於テハ小池. 細谷. 田中. 赫松，大內。吉时，山口 3 氏協同．四尼等/報 告ガフルガ. 多数症例二就テ览細二觀察セラレ

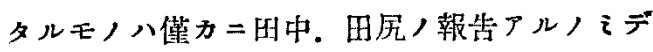
フル。

演皆八昭和 13 年 1 月ヨリ東京付東村山村二存

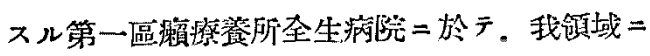

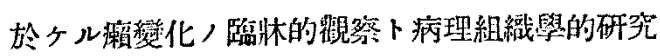

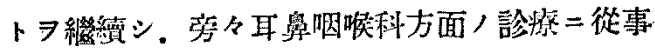

